\title{
The Role of Human Resource Management Indicators in Social Enterprises with Special Regard to the Social- Cooperatives
}

\section{Sándor Bozsik}

Ph. D, associate professor, University of Miskolc, Faculty of Economics

Judit Szemán

Ph. D, associate professor, University of Miskolc, Faculty of Economics

Zoltán Musinszki

Ph. D, associate professor, University of Miskolc, Faculty of Economics

\section{Abstract}

The social enterprises play a vital role in a daily operation of smart cities. They can provide these towns with flexibility and innovation skills and help to maintain the social peace to provide work with the less competitive part of smart cities' population. (Bartha-Bereck, 2018) This paper focuses this latter task. The social co-operatives offer an opportunity to improve the employment skills. However, the management of this enterprises faces several dilemmas how can build up an effective control system of a social enterprises in Central-Europe. As our questionnaire stated, the major problem of social cooperative is the quality of available labour force. This paper focuses the applicability of the traditional Balanced Scorecard system to the special needs of a Social Enterprises. Here one area of the Balances Scorecard will be highlighted - the Human Resource management and how the tools can be effectively adapted to the social cooperatives. A report system and a ratio analysis tool is developed to help the work of social cooperative managers.

Keywords: social enterprises, social co-operatives, human resource management, key performance indicators, balanced scorecard

\section{Introduction}

This paper is devoted to the Human Resource Management issues of Hungarian Social Cooperatives. 
The authors have got the opportunity to teach the managers of these special enterprises in a frame of a countryside compulsory programme organised by their supervisory agency. The participants of these trainings can fill a questionnaire which focuses the managerial problems of social cooperatives. Using the learning points of this questionnaire, we tried to implement a tailor- made Balance Scorecard System to the specific needs of the Hungarian social cooperatives. This paper covers the Human Resource Management part of this Balanced Scorecard System.

In our paper we briefly overview the development of Balanced Scorecard Systems, than interpreted the related questions from our questionnaire, and then we suggested an indicator system which meets the criteria of the supervisory agency and the internal management of social cooperatives.

\section{Brief Literature Overview - The Development of Traditional Management Performance System to the Balanced Scorecard}

The management information system collects the data from the accounting system, so the most important source of data is the annual report of a company. Financial statements are a structured representation of the financial position and financial performance of an entity. The objective of general-purpose financial statements is to provide information about the financial position, financial performance and cash flows of an entity that is useful to a wide range of users in making economic decisions.

The users of financial statements can predict the entity's future cash flows and, in particular, their timing and certainty.

The International Accounting Standard 1: Presentation of Financial Statements sets out the requirements for the components of financial statements as follows:

- balance sheet,

- income statement,

- statement of changes in equity

- cash flow statement,

- notes (comprising a summary of significant accounting policies and other explanatory notes). [1, 8. par.]

Balance sheet is a statement of financial position at the end of a period (end of the business year) in terms of assets and financing (liabilities and ownership equity). The income statement presents the results at the end of a period of activity. It presents information on the profit and loss and other comprehensive income. Statement of changes in equity, analysis of other comprehensive income and statement of cash flows are also required by the IAS 1 standard.

From the financial statements a multitude of indicators can be formed. The traditional financial indicators provide information about the property, financial and profitability state. They can give a view about: 
the structure of the assets and the liabilities,

the effectiveness of the assets,

the amount of the debt,

the liquidity,

the profitability relative to the various projection bases.

During the analysis of the balance sheet we can draw conclusions about the property and financial state of the enterprise, and from the cash- flow about its financial state. (Fenyves et al, 2019)

In addition to individual financial indicators, we can also use indicator systems. One of the most popular indicator systems is the Du Pont system. It is based on the idea that not profit -- as an absolute indicator -- is in the centre, but the Return on Investment (ROI) - as a relative value. The top indicator of the system is the ROI that is definable as the ratio of the net outcome and the net asset value. The strength of the ROI that it is not an individual indicator, but an indicator system whose elements carry important information for the decision maker. This indicator can be further divided into two indicators: the profit margin and the turnover rate of the assets to the revenue. These two indicators can be further distributed by the outcome, cost, asset and liability data are the responsibility of the leader of a given decentralised unit.

The financial statements' data are typically aggregated data. These highly summarized data give an overall picture of the company's management. They help us to see the problems, and to know where to look for the source of the problems, but it does not give answers for the causes of problems. We tend to ask questions in the analysis of financial statements, rather than to formulate answers. However, there is a big problem. Only financial indicators can be calculated from the financial statements. The traditional financial indicators applied as the benchmark of the enterprises cannot provide appropriate information to the management for the following reasons:

- The traditional financial indicators inform about the companies' past achievement; they do not have connection with the future.

- They are unsuitable for the prevention of problems, namely they take into account the effects of the organizational actions and consumer choices that have already occurred.

- They are short- term in approach, and therefore cannot serve the aims of the company strategy.

- They are not diagnostic featured: they show the problems but cannot point out the root cause.

Due to being set in terms of money, they cannot be used for displaying qualitative factors, although the achievement of an enterprise consists of both quantitative and 
qualitative elements connected to the performance of the tasks assigned by the company. (Demény-Musinszki, 2016)

Despite the criticism of the use of traditional financial indicators enjoy a great popularity. Their advantages are the simplicity, the availabilities and the cheapness However, their application based on the literatures' recommendation have dangers. (Brealey et al., 2011)

Nowadays the economic environment of companies has significantly changed: the former permanence was replaced by variability, marketing has come into the focus of operation instead of production, and the knowledge-focused approach has appeared beside the capital-centred approach. (Veresné Somosi, 2010)

\section{Figure 1 - From financial indicators to balanced scorecard}

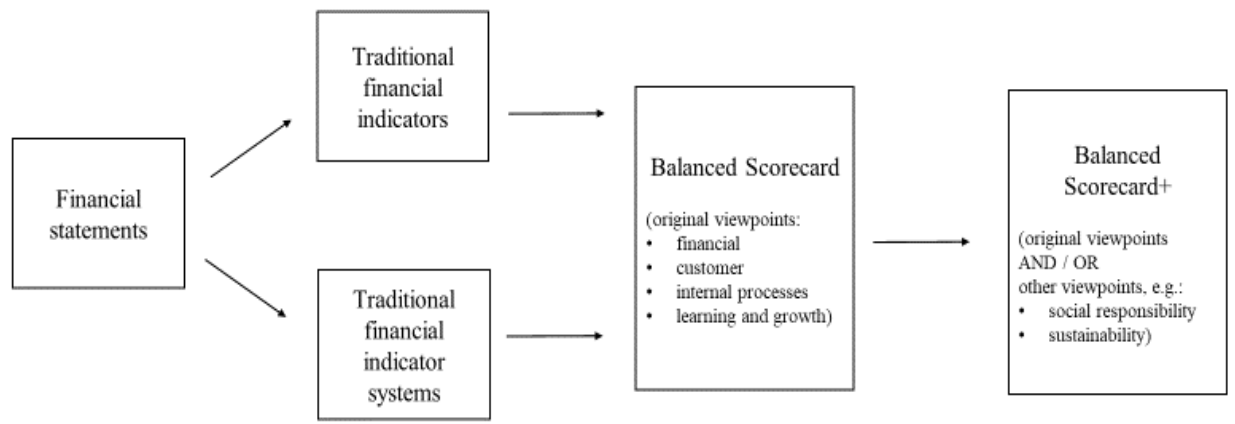

Source: own editing

In today's highly competitive environment the financial indicators alone are not able to give direction for the future; typically, they can give a view about some actions of the past, and so are retrospective, post factum indicators. In recognition of the changes, Robert S. Kaplan and David P. Norton developed a balanced, strategy-based indicator system. Both financial and non- financial indicators need to be reflected in the benchmark. The balance between them has to be created and they have to be united in a complex indicator system. This is achieved by the Balanced Scorecard (BSC). The viewpoints of the basic model (financial, customer, internal processes, learning and growth) are looking for answers for four questions:

What are the expectations of the stakeholders?

What kind of achievement is expected by the customers?

In which processes is it necessary to provide outstanding performance?

How may the change and developmental ability be maintained in the future? (KaplanNorton, 1992) 
However, the basic model was not regarded as a definite model by the model creators. Over the last two decades different types of the basic model have been revealed taking different factors into consideration. The number of viewpoints has expanded:

- the supplier,

- the future,

- social responsibility and

- sustainability has become independent viewpoints. (Molnár-Horváth, 2017)

\section{Methodology - Managerial Problems of Social Cooperative}

One of the issue what we walked around in the questionnaire was the managerial problems of social cooperatives. The question was the following: "Please rank by importance of the following problems in the management of social cooperative" 72 social cooperative managers were asked from region of South-Transdanubia, Southern Plain, and Northern Plain.

Sixteen potential sources of managerial problems were listed, and the respondents were asked to rank the problems by their seriousness in the economic management of their organisation. The answers are presented in figure 2 .

Figure 2: Significance of economic problems in the management of social cooperatives

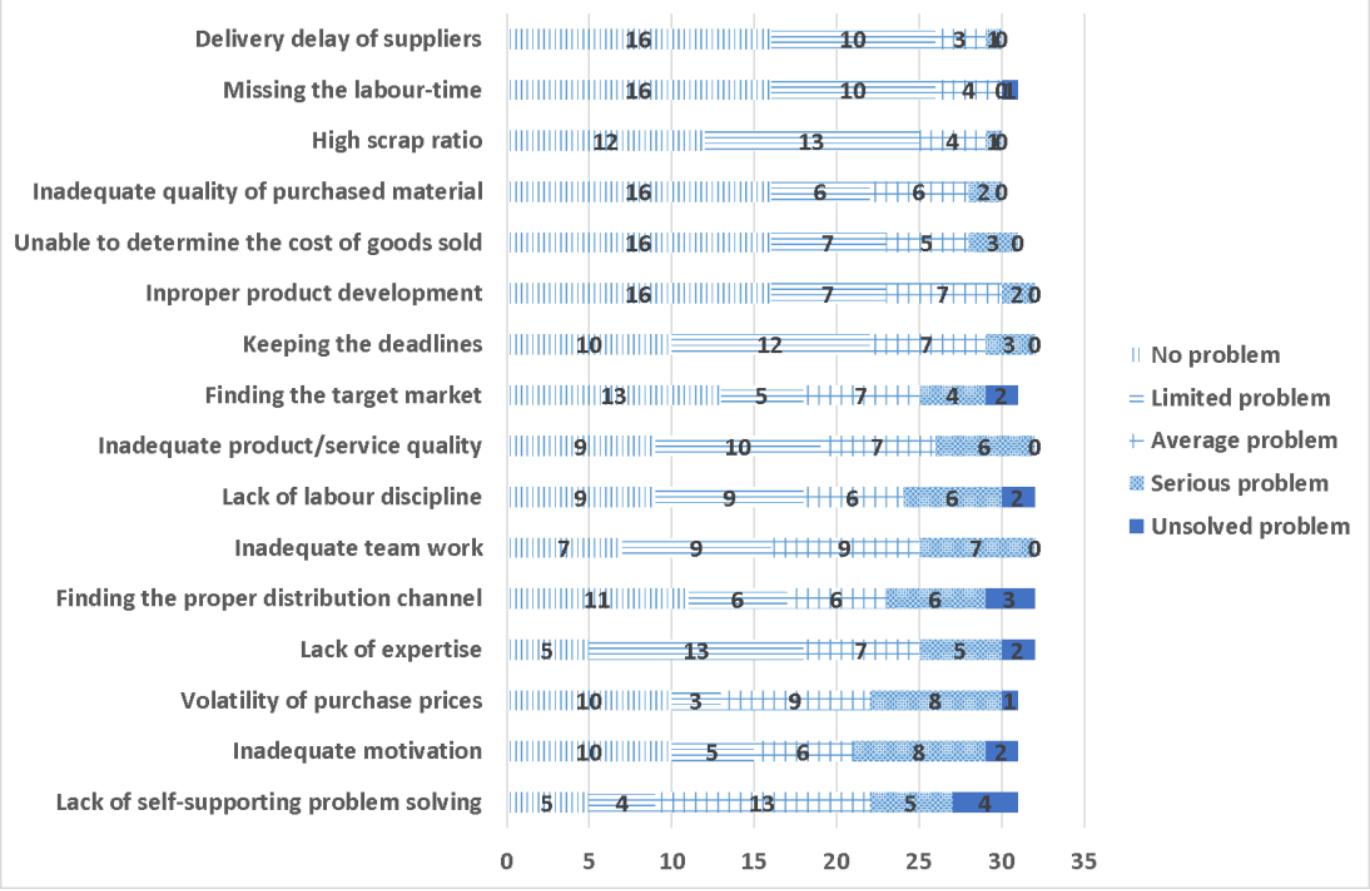

Source: Own editing 
The respondents evaluate the importance of each of the sources at a 5 points Likertscale. (no problem - 1; limited problem - 2; average problem - 3; serious problem 4 and unsolved problem - 5) The weighted average of the answers was calculated, where the weights were the number of answers in each category. To calculate the ranking, we took the weighted average of the total answers and ranked them in ascending order, so the less important problem is at the top, while the most important one is at the bottom.

If we look at the rank of the problem, the most serious problems are caused by the improper work force. Lack of self-supporting problem solving - first on the list, Inadequate motivation - second on the list, lack of expertise - fourth on the list, inadequate teamwork - sixth on the list, lack of labour discipline - seventh on the list. Almost every aspect of the work force is critical except of the labour-time which is a negligible problem. It is no wonder, the workers are paid after their working hours regardless to their performance. The condition of granting state subsidy is the employment of the dedicated employees, so if the social cooperatives dismiss an employee, a new one should be taken. Considering the fact, that these social cooperatives are mostly operating in small settlements (see table 2), to find new employees replacing the improper ones are very hard task.

The main aim of the state subsidy is to help the people to transfer from the longlasting unemployment or public work status to a marketable employment. But the answers to this question indicate, that this transformation is not an easy job. To improve the quality of available work force requires the constant supervision of the management and the targeted training of the employees to satisfy the labour market requirements.

The respondents find the second main problem group in the improper marketing (find the proper distribution channel - ranked at $5^{\text {th }}$ biggest, problem of 16 , inadequate product/service quality - ranked at $8^{\text {th }}$, finding the target market - ranked at $9^{\text {th }}$ improper product development - ranked at $11^{\text {th }}$ ). The social cooperatives mostly work up local raw materials and selling them in short distance markets. Considering the fact, that they are new organisations and definitely small ones (see on table 2), their brand strength is very limited. But they cannot compete with prices, because the cost of operation is high due to the improper work force and the limited size of production. To break out from this trap requires proper business cases and perfect implementation of business plans.

The next problem circle related to the uncertainty of purchase (volatility of purchase prices - ranked at $3^{\text {rd }}$ biggest problem). The other problems relating to the purchase are far less important. (reliability of purchase quality - $13^{\text {th }}$, delivery delay of suppliers - last one). The quality management of internal processes (keeping the deadlines $-10^{\text {th }}$, unable to determine the cost of goods sold $-12^{\text {th }}$, high scrap ratio $14^{\text {th }}$ ) is less important. 
To sum up our result, the far most important problem of the management of social cooperatives is the improper quality of labour force. Almost every aspect related to human resource management were considered as critical factor. The marketing problems are also important, the issues related to the internal processes and purchase are less significant.

\section{Discussion - Optional Solutions of the Managerial Problems}

The main line of our research, how the managers of social cooperatives can use the databases available at their organization to make proper decisions. The framework of the structured usage of databases worked out by Kaplan and Norton (Kaplan and Norton, 1992) and it is called to Balanced Scorecard System (further BSC). The viewpoints of the basic model are the financial, the customer, the internal processes, and the learning and growth viewpoint.

Bull's paper analysed the results of 30 pilot social enterprises utilizing the BSC system. The paper concluded that highlighting both strengths and areas where greater support may be required would be a great help for these enterprises. (Bull, 2006)

He stated that the SEs general strengths by his investigation is the learning perspective. (i.e. training and development, participative decision-making and personal development cultures) The other strong area is the vision and strategy creation ability.

The weaknesses are the low level of management system from the accounting to the quality standards. The reason is the shortage of resources like financial literacy, professional skills and moral hazard.

Bull also modified the original BSC model to SEs by modifying the four perspectives into: multi-bottom line (dealing with synthetic assessment of financial, environmental and social results), stakeholders' environment, internal activities (related to structure, communication, quality, etc.), and learning organization (dealing with training and knowledge management). 
Figure 3 - Bull's Balance Model and Topic Areas

\begin{tabular}{|c|c|c|c|}
\hline \multicolumn{2}{|c|}{ Return: The multi-bottom line } & \multicolumn{2}{|c|}{ A learning organisation } \\
\hline \multicolumn{2}{|l|}{ Social Accounting } & & \multirow{5}{*}{$\begin{array}{l}\text { Learning Culture } \\
\text { Improvement } \\
\text { Participation } \\
\text { Knowledge } \\
\text { Continuous Improve. } \\
\text { Training }\end{array}$} \\
\hline Sustainability & & & \\
\hline Budgets & & & \\
\hline Social Aims & & & \\
\hline $\begin{array}{l}\text { Environmental Aims } \\
\text { Metrics }\end{array}$ & \multirow{2}{*}{\multicolumn{2}{|c|}{$\begin{array}{c}\text { Visioning } \\
\text { (Mission Statement, } \\
\text { Balance Sheet, Business } \\
\text { Plan) }\end{array}$}} & \\
\hline Branding & & & $\begin{array}{l}\text { Structure } \\
\text { Communication }\end{array}$ \\
\hline & & Quality \\
\hline & & & Standards \\
\hline \multicolumn{2}{|l|}{ Stakeholder Focus } & & Frexibility \\
\hline \multicolumn{2}{|l|}{ Market Awareness } & & Performance Measures \\
\hline \multicolumn{2}{|c|}{ The stakeholder environment } & \multicolumn{2}{|c|}{ Internal activities } \\
\hline
\end{tabular}

Source: Bull, 2006

By our review the main problem of social cooperatives is related to human resources. (Kocziszky , 2017) The monitoring of this problem is treated by the human resource and learning perspective of BSC. The key point of the learning perspective is: How can the employees and the management treat the challenges of the continuously changing economic environment, how quick is the implementation of the proper answers?

The key point of the customer perspective is: How do customers judge the performance of the organization? When designing a customer perspective, it is necessary to identify the customers, market segments where the organization wants to compete. Financial goals can only be met by the organization if it produces products or services that customers value. We are not able to satisfy every customer's needs, so it is advisable to set target values by segment. Thus, the customer aspect basically focuses on the long-term relationship with the customers being fruitful and durable. Based on Kaplan's and Norton's recommendations (Kaplan and Norton 1992), the market share, product range, customer satisfaction, complaints, returns, customer group profitability, retained and new customers, etc. are the related indicators. (Musinszki and Süveges 2019)

The purchase problems can be well treated by the internal processes' perspective of BSC as like the quality management.

That is the reason, why the classic Bull-model is modified reflecting the problems detected by our questionnaire. 
The financial accountability is an important part and key issue for every enterprise, so we only slightly modified the left upper segment. However, we replace the environmental aims to financial and environmental solvency.

One of the missions of the social enterprises is to help their member to develop and improve the important labour market abilities. Since in the learning organization perspective we inserted new aspects which emphasize the improvement of the competitiveness of the labour force. This part is considered as the most important part of the BSC, because the success of improving the human resource factors will improve the financial perspective.

The stakeholder environment was dramatically restructured. Instead of it we place the requirements of the grantor and regulator public institutions. Most of the social enterprises depends of public funds, so the enterprises should meet the criteria of the state and European funds. The available state funds can be numerous. Especially in the agriculture and country development there are several opportunities. (Olajos, 2019)

The internal activities strive to enhance the efficiency of operations. We plan here only one modification. How can the social enterprise develop the members' relevant labour market abilities?

Figure 4 shows the result of our considerations. The suggested modification in the original model are bolded.

Figure 4 - Further developed Bull model to the social cooperatives

\begin{tabular}{|c|c|c|c|}
\hline \multicolumn{2}{|c|}{ Return: The multi-bottom line } & \multicolumn{2}{|c|}{ A learning organisation } \\
\hline \multicolumn{2}{|c|}{$\begin{array}{l}\text { Social Accounting } \\
\text { Financial and environmental } \\
\text { sustainability }\end{array}$} & & \multirow{2}{*}{$\begin{array}{l}\text { Learning Culture } \\
\text { Improvement } \\
\text { Participation } \\
\text { Marketable competenc } \\
\text { Adaptation of labour } \\
\text { market skills }\end{array}$} \\
\hline $\begin{array}{l}\text { Social Aims } \\
\text { Labour market cost }\end{array}$ & \multirow{2}{*}{\multicolumn{2}{|c|}{$\begin{array}{c}\text { Visioning } \\
\text { (Sustainable labour market } \\
\text { activity and fulfilling other } \\
\text { social goals ) }\end{array}$}} & \\
\hline \multirow{2}{*}{$\begin{array}{l}\text { Structure and } \\
\text { compensation of } \\
\text { employees } \\
\text { Fit to the request of } \\
\text { financing organisation } \\
\text { Financial and non-fina } \\
\text { reports }\end{array}$} & & & \multirow{2}{*}{$\begin{array}{l}\text { Structure } \\
\text { Communication } \\
\text { Quality } \\
\text { Standards } \\
\text { Developing labour } \\
\text { market skills } \\
\text { Performance Measures }\end{array}$} \\
\hline & ncial & & \\
\hline \multicolumn{2}{|c|}{ Fulfil the request of public donors } & \multicolumn{2}{|c|}{ Internal activities } \\
\hline
\end{tabular}

Source: Bozsik et al, 2019 
To monitor the dedicated issues of a BSC system, the size of the problem should be measured by indicators, the frequency of measurement should be determined, furthermore the circle of potential actions to improve the indicators.

The interpretation of the figure is started from the left upper corner and move downwards and to right.

The multi-bottom line means that the social cooperatives has got duel goals - a market one and a social one. The market goal is to increase the equity of the organisation by achieving positive net income which is the bottom-line figure of the income statement. The social goal can be seen in the very middle of the figure - to provide a sustainable employment of their member and create a marketable work force from the employees.

The financial sustainability reflects the market goal. The organisation should be profitable (proposed indicator is the ROE - return on equity - where the net income is divided by the equity of the social cooperatives). Other profitability indicator can be also used - for example Return on Assets, EBITDA ratio.

The labour market cost is essential, because the operating state subsidy can cover 50 $100 \%$ of this expense. And replacing the state subsidy with own revenue is the key success indicator of the social cooperative. The proposed indicator here is the operating state subsidy/total labour cost - which should be reduced over time. Other indicator can be the operating state subsidy/operating profit. If the ratio is less than one, the organisation can be considered as a sustainable organisation, because it is able to survive without the operating state subsidy. (Lipták, 2017)

The above indicators are used to measure the result of the operations, but they are unable to measure the reasons of the success or failure. From the questionnaire you can see, that the major problem is the quality of available work force. So, the improvement of the human resource by learning and by motivating is essential. The upper right quarter of our proposed BSC related with issue.

The marketable competence can be measured by several indicators, but they are industry specific ones. Each industry requires special features. For manufacturing enterprises, the proper quality of craftsmen can be regularly tested, and the essential training program should be introduced. Here the proposed indicators are the ratio of skilled and unskilled labour force. The successful completion of vocational training programs is also worth measuring. To improve the teamwork and the motivation independent projects should be launched with the management of a team leader. The goal and reward of these projects should be specifically determined, and their continuous monitoring is required.

The request of the donor public organisation can be various. They often prescribe the number of employees or members, the length of their employment, they can limit the amount of payable transfers. In addition to the circumstances of employment they can 
order numerous data service about the activity of the social enterprises, determine the major accounting and taxation policy rules, the structure and content of financial reports, they can require financial budget.

Public institutions can act as an external control over the business of social enterprises.

\section{Analysis - Tasks of Human Resource Management}

The importance of human factor is vital in the operation of any enterprise. The Human Resource Management is not else than the implementation of traditional controlling methods (i.e. goal setting, planning, plan-fact analysis, corrective actions). The main aim of a general Human Resource Management is to give a real, transparent, actual overview on the staff's employment skills and to give advice how to face the different challanges like recruiting, career planning, dismissing, employee satisfaction. The financing issues are also part of this job - payroll calculation, working out material incentives, efficiency analysis of labour force.

\section{Regulatory framework}

The social cooperatives can be established by the Act on Cooperatives (2006/X..) The special rules of social cooperatives are determined by the government order 141/2016. An application was written out for supporting the creating socialcooperatives called „Focus programme for promoting social cooperatives with local government membership”. („Fókuszban ..., 2016)

Most of the social cooperatives are established to utilise the opportunities offered by the Focus programme. The condition of this Application was that at least two of members should be earlier public worker, and the employees should be former unemployee, student or pupil. (Katonáné et al., 2017) The requirements of the Application related to the Human Resource Management were the followings:

The social cooperatives should ensure new and long lasting employment up to 2020 for those, who were former unemployed, or public workers.

The social cooperatives can apply for a subsidy up to 7,5 million forint/annum/person to cover the gros wage and social contribution tax. In the first year the sum of subsidy can reach the $100 \%$ of this amount, in the second year it decreased to $90 \%$, in the third year to $80 \%$.

One project manager can receive a monthly payment up to the twice of the minimal wage + its contribution tax and travelling cost from this subsidy.

At least two members of the social cooperatives should take part a social manager training and annually at least 6 members should attend in a two days long community building training. 
Semiannually the social cooperatives can require advisors from one of the following areas (Labour Law, Finance, Sustainability or Marketing Management), and annually it can be supplied with consultant in field of organisational development or racionalisation or Human Resources Management. These external experts and the trainings are financed by the supervisory authority called OFA (National Employment Fund).

Furthermore it can be applied for additional and optional advisory support like technical advisory work for implementing investments and equipment purchase, commercial activities.

To monitor the activity of the social cooperatives the supervisory authority also requires regular reports. Some of them are also related to the Human Resource Management. These are the followings:

Monthly report on the number of employment (in- and outgoing staff)

Quarterly report on the professional progress of employee taking part in various development programmes.

Quarterly report on involvement of external advisors (goal, task, evaluation of success)

\section{Budget statements}

To meet the requlatory framework the social cooperatives requires carefully planning of employment. The managers should consider meeting the requirements of application during the decision making. The level of employment is important condition of granting subsidies, so more emphasis is needed to develop the skills and attitude of existing labour force rather replacing them with more motivated and skilled ones. The regular training programmes and the acquirement of foreign experts also supports this approach.

The base and starting point of any budget process is the personal file which has to be updated for each of the employee. The proposed content of this file is in tables below:

Table 1/a - Descriptive data of employee:

\begin{tabular}{|l|l|}
\hline Name: & \\
\hline Tax number: & \\
\hline Sex: & \\
\hline Position: & \\
\hline Graduation: & \\
\hline Professional skills: & \\
\hline Special abilities: & \\
\hline Family status: & \\
\hline Other tax allowances: & \\
\hline
\end{tabular}




\begin{tabular}{|l|l|} 
Health status: & \\
\hline Date of recruitment: & \\
\hline
\end{tabular}

Source: own editing

The data on family status and health status is not only important, because it helps characterise the employees, but also important information to acquire the tax allowances in personal tax. The other tax allowances regard mainly to the social contribution tax allowances.

Besides the qualitative information, information about the financial incentives are also worth to record. We need them to meet the data service requirements of the authorities and to complete the tax declarations.

Table $1 / \mathrm{b}$ - Outgoing payments and incentives

\begin{tabular}{|l|l|l|l|l|}
\hline \multicolumn{5}{|c|}{ Payroll/Sick payment/Benefits in kind } \\
\hline Period & $\begin{array}{l}\text { Length (in } \\
\text { month) }\end{array}$ & Salary & $\begin{array}{l}\text { Social } \\
\text { contribution }\end{array}$ & Total \\
\hline & & & & \\
\hline & & & & \\
\hline
\end{tabular}

Source: own editing

Table $1 / \mathrm{b}$ summarises the content of three tables, whose purpose can be read in the headings. We should separate the salaries from the benefits in kind and sick payment, while their taxation are different.

The third element of the personal file or record is the information about the employee's personal development. Its structure is below:

Table 1/c - Record on personal development

\begin{tabular}{|l|l|l|l|l|}
\hline \multicolumn{3}{|l|}{ Personal development } & & \\
\hline Date & $\begin{array}{l}\text { Type of } \\
\text { training }\end{array}$ & Graduation & $\begin{array}{l}\text { Potential } \\
\text { utilisation }\end{array}$ & $\begin{array}{l}\text { Actual } \\
\text { utilisation }\end{array}$ \\
\hline & & & & \\
\hline & & & & \\
\hline
\end{tabular}

Source: own editing

The second input of the Human Resource Controlling is the strategic plan of the social cooperatives. In budgeting the management should make decisions on the personal development of the employees and also on the application for external experts. If theses strategic decisions are made, the management can budget and monitor the Human Resource Activity by using the following tables.

Table 2 - Labour cost budget 


\begin{tabular}{|c|c|c|c|c|c|c|c|c|c|}
\hline \multirow{2}{*}{\multicolumn{2}{|c|}{ Labour cost budget }} & \multicolumn{3}{|c|}{ Month } & \multicolumn{5}{|c|}{ Total } \\
\hline & & January & $\ldots$ & December & Q1 & Q2 & Q3 & Q4 & Total \\
\hline \multirow{3}{*}{ Salary } & Budget & & & & & & & & \\
\hline & Actual & & & & & & & & \\
\hline & Difference & & & & & & & & \\
\hline \multirow{3}{*}{ Social contribution } & Budget & & & & & & & & \\
\hline & Actual & & & & & & & & \\
\hline & Difference & & & & & & & & \\
\hline \multirow{3}{*}{ Sick payment } & Budget & & & & & & & & \\
\hline & Actual & & & & & & & & \\
\hline & Difference & & & & & & & & \\
\hline \multirow{3}{*}{ Benefits in kind } & Budget & & & & & & & & \\
\hline & Actual & & & & & & & & \\
\hline & Difference & & & & & & & & \\
\hline \multirow{3}{*}{ Total } & Budget & & & & & & & & \\
\hline & Actual & & & & & & & & \\
\hline & Difference & & & & & & & & \\
\hline
\end{tabular}

\section{Source: own editing}

Table 2 is simply an aggregation of the financial outgoing part of the personal files. In the beginning of the year the management budgets the future payments and compares with the actual payments. The figures are aggregated quarterly (see Q1, Q2, Q3 and Q4) and annually. The quarterly aggregation is necessary to complete the quarterly report to the supervisory authority.

The table can be extended with the source of labour cost (i.e. amount of state subsidy and own source).

Table 3 - Budget on personal development

\begin{tabular}{|c|l|l|l|l|l|l|}
\hline \multicolumn{2}{|c|}{ Personal development } & Q1 & Q2 & Q3 & Q4 & Total \\
\hline \multirow{2}{*}{$\begin{array}{c}\text { Social management } \\
\text { training }\end{array}$} & Budget & & & & & \\
\hline & Actual & & & & & \\
\hline & Difference & & & & & \\
\hline $\begin{array}{c}\text { Community building } \\
\text { programme }\end{array}$ & Budget & & & & & \\
\hline & Actual & & & & & \\
\hline \multirow{5}{*}{$\begin{array}{c}\text { Other occassions } \\
\text { Difference }\end{array}$} & Budget & & & & & \\
\hline & Actual & & & & & \\
\hline & Difference & & & & & \\
\hline \multirow{2}{*}{\begin{tabular}{l} 
Total \\
\cline { 2 - 7 }
\end{tabular}} & Budget & & & & & \\
\hline & Actual & & & & & \\
\hline & Difference & & & & & \\
\hline
\end{tabular}

Source: own editing 
The following tables contain information about the budgeted and actual personal development actions. Each of the budgeted and actual actions should be registered in the personal files too.

Table 4 - Supportive actions

\begin{tabular}{|c|l|l|l|l|l|l|}
\hline \multicolumn{2}{|c|}{ Supportive actions } & Q1 & Q2 & Q3 & Q4 & Total \\
\hline \multirow{4}{*}{ Accounting\&Finance } & Budget & & & & & \\
\hline & Actual & & & & & \\
\hline & Difference & & & & & \\
\hline \multirow{3}{*}{$\begin{array}{c}\text { Marketing \& } \\
\text { Commercial }\end{array}$} & Budget & & & & & \\
\hline & Actual & & & & & \\
\hline \multirow{3}{*}{ Dechnical } & Difference & & & & & \\
\hline & Budget & & & & & \\
\hline & Actual & & & & & \\
\hline \multirow{2}{*}{ Total } & Difference & & & & & \\
\hline & Actual & & & & & \\
\hline & Difference & & & & & \\
\hline
\end{tabular}

Source: own editing

The supportive actions depend on the management of the social cooperatives. Besides the quantitative data, it would be useful to store data about the advisory problem, the persons involving in the advisory work and the usefulness of the advisory report in point of future success.

\section{Indicators}

To monitor the state of staff, some traditional human resource indicators also can be used. The indicators should be measured quarterly, and the tendency reflects the improvement or deterioration of staff satisfaction. The ratios support the balance scorecard mechanism.

In case of social cooperatives we suggest to use the labour cost ratio as a key performance indicator.

Labour in value added ratio $=\frac{\text { quarterly labour cost }(\text { thousand forint })}{\text { value added (thousand forint) }}$

The value added is the difference between quarterly sales and quarterly material cost and other expenses except of depreciation and labour cost. Since the labour cost and most of asset purchase is actually financed from state subsidy, the current value of ratio can be higher than 1 . However, the economic entity should be sustainable, so the major aim of the social company to reduce this ratio to less than 1 . The lower the ratio, the higher the amount, which the company can devote for further development and 
investment. This ratio can be distributed into three further indicators in the following way:

Labour in value added $=$ Labour economical $*$ Labour efficiency * Labour effectiveness The ratios are interpreted below:

Labour economical ratio $=\frac{\text { labour cost (thousad forint })}{\text { potential working days (head } * \text { days })}$

The dimension of this ratio is forint/head/days. In case of social cooperatives its value mostly depends on the current level of daily minimal wage. The higher than minimal value indicates higher generosity of social cooperatives or higher ratio of skilled labour.

Labour efficiency ratio $=\frac{\text { potential working days }(\text { head } * \text { days })}{\text { active working days }(\text { head } * \text { days })}$

The ratio can be 1 or higher. If the ratio is 1 , every employee works during the month. Naturally the potential minimum is likely not reached. The paid and unpaid holidays, the sickness can increase this figure. A sharp increase in this ratio indicates a mass holiday, but also a worsening attitude of labour activity.

Labour effectiveness ratio $=\frac{\text { active working days (head } * \text { days) }}{\text { quarterly sales (forint) }}$

The dimension of this ratio is head*days/forint. It measures how many labour time is required to produce 1 thousand forint value added. The lower the ratio, the better the effectiveness of the labour.

Not the absolute size of the ratios is important, but the size of their changes, which we can discover a logarithmical distribution in the following way.

$$
100 \%=\frac{\ln (\triangle E C O)}{\ln (\Delta L V A)}+\frac{\ln (\triangle E F I)}{\ln (\Delta L V A)}+\frac{\ln (\Delta E F E)}{\ln (\Delta L V A)}
$$

where,

$\triangle \mathrm{LVA}$ - ratio of two comparable labour in value added ratio;

$\triangle \mathrm{ECO}$ - ratio of two comparable labour economical ratio;

$\Delta \mathrm{EFI}$ - ratio of two comparable labour efficiency ratio;

$\triangle \mathrm{EFE}$ - ratio of two comparable labour effectiveness ratio;

\section{Conclusion}

As we can see from the questionnaire, the Human Resource Management plays a vital role in the social co-operative's management. A controlling system was developed to monitor and to observer the current state and the development of labour force in a social co-operative. The proposed managerial control system consists of two parts. 
A table structure was developed to fulfil the requirements of the reporting system determined by the regulatory authority. The tables focus the cost of labour, the development of human resource and the supportive actions. The proposed frequency is in case of individual record is monthly, for aggregated figures quarterly.

A ratio analysis tools was implemented to analyse the current state and the development of labour force. The analysis monitors the utilization of human resource and identifies three driving factors:

Economical factor measures the cost of labour per potential working days.

Efficiency factor measures how relates the potential working days to the actual working days.

Effectiveness factor measures the productivity of the available labour source.

Naturally the ratios can be calculated not only the cooperative aggregate level, but can examine in different product lines if they exist.

\section{Acknowledgement}

This research was supported by the project no. EFOP-3.6.2-16-2017-00007, titled Aspects on the development of intelligent, sustainable and inclusive society: social, technological, innovation networks in employment and digital economy. The project has been supported by the European Union, co-financed by the European Social Fund and the budget of Hungary.references.

\section{References}

[1] Bartha Z. - Bereck Á. (2018) „a Társadalmi Vállalkozások Sikertényezői, Erősségei És Gyengeségei" in: Vállalkozásfejlesztés An Xxi. Században Viii./2. Makro- És Mikrokörnyezeti Trendek És Kihívások a Vállalkozásfejlesztésben Óbudai Egyetem, Keleti Károly Gazdasági Kar 2018, Budapest, Magyarország Isbn 978-963-449-094-4 6-20. Oldal

[2] Bozsik S. - Musinszki Z. - Szemán J (2019) "a Central European Approach to the Typology of Social Enterprises" in: Proceedings of the $13^{\text {th }}$ International Conference of Strategic Management and Its Support by Information Systems Smsis 21-22 May, 2019 Ostrava Czech Republic Issn: 2570-5776 Pp. 25-32.

[3] Brealey R. - Myers S. - Allen F. (2011). "Principles of Corporate Finance" Mcgraw-Hill/Irwin, New York, 10th Edition

[4] Bull M. (2006). 'Balance' the Development of a Social Enterprise Business Performance Analysis Tool - the Third Annual Social Enterprise Research Conference 22-23 June 2006 London South Bank University Doi: $10.1108 / 17508610780000721$ 
[5] Demény a. - Musinszki Z. (2016) "Social Accounting - in the Wake of the Sustainability" Theory Methodology Practice: Club of Economics in Miskolc 12:(02) Pp. 26-40.

[6] Fenyves V. (Et Al.) (2018) "the Role of the Notes to the Financial Statements in Corporate Decision-Making” Corporate Ownership and Controls 15:4 Pp. 138-148.

[7] Fókuszban Az Önkormányzati Tagsággal Rendelkező Szociális Szövetkezetek Támogatási Program (2016) Http://Palyazatok.Org/WpContent/2016/07/Palyazati Felhivas Utmutato.Pdf

[8] Kaplan, R. S. and Norton, P. D. (1992). "the Balanced Scorecard - Measures that Drive Performance" Harvard Business Review, 92/1-2, Pp. 71-79.

[9] Katonáné J. - Varga E. - Nemes G. (2017) „Fókuszban a Társadalmi Innováció Folyamata a Magyar Vidéken" Észak-Magyarországi Stratégiai Füzetek Xiv. Évf. 1. Szám 6-19. Oldal

[10] Kocziszky, Gy., Veresné, S.M. and Balaton, K. (2017). a Társadalmi Innováció Vizsgálatának Tapasztalatai És Fejlesztési Lehetőségei, Vezetéstudomány, Vol. 18, No. 6-7, Pp.15-19.

[11] Lipták K. (Szerk.) (2017) „Társadalmi Innováció És Felelősségvállalás ÉszakMagyarországon” Miskolci Egyetem Gazdaságtudományi Kar Isbn 978-963358-135-3

[12] Molnár V. - Horváth D. (2017) “Determination of Coefficients of MultiAttribute Utility Function with Attribute Breakdown" Proceedings of the 12th International Conference on Strategic Management and Its Support by Information Systems Ostrava, 2017., Pp. 312-319.

[13] Musinszki Z. - Süveges G. (2019) “Strategic Decision-Making Supported by Traditional Financial Indicators" Oradea Journal of Business and Economics Vol. 4, No. 1. Pp. 29-37

[14] Olajos I. (2019) a Fiatal Gazda Tematikus Alprogram, Mint a Támogatási Rendszer Kiemelt Eszköze - Publicationes Universitatis Miskolciensis Sectio Juridica at Politica (Under Publishing)

[15] Veresné Somosi M. (2010) "the Self-Evaluation Model of Organizational Behaviour" European Integration Studies, 2010/1., Pp. 227-237. 